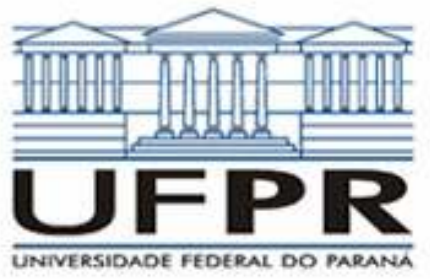

\author{
Programa de Pós-Graduação em \\ Desenvolvimento Econômico - PPGDE \\ Universidade Federal do Paraná
}

Texto para discussão PPGDE 2006/9

\title{
The metaphors of Transaction Cost Economics
}

\author{
Huáscar Fialho Pessali \\ Departament of Economics \\ Federal University of Paraná, Curitiba, Brazil \\ E-mail: pessali@ufpr.br
}

PPGDE, UFPR

2006 


\title{
The metaphors of Transaction Cost Economics
}

\author{
Huáscar Fialho Pessali \\ Departament of Economics \\ Federal University of Paraná, Curitiba, Brazil \\ E-mail: pessali@ufpr.br
}

\begin{abstract}
Metaphors are part of our daily lives as they help us understand the world and economics, as other areas of knowledge, cannot go without metaphors. Transaction Cost Economics (TCE) is no different to other intellectual construction and has been built on a set of key metaphors. This article discusses three of these metaphors: transaction costs as frictions, human beings as "contractual men," and natural selection between mechanisms of governance. It scrutinises their potential to help Williamson's theory gain adherence from and be recognised as relevant by his peers. It discusses some possibilities of how the initial choice or formulation of key TCE metaphors may mould intellectual exchanges and direct theoretical developments.
\end{abstract}

Keywords: transaction cost economics, metaphors, Oliver Williamson, theory of the firm, institutions of economics, institutional economics 


\title{
The metaphors of Transaction Cost Economics
}

\author{
Huáscar Fialho Pessali
}

\section{INTRODUCTION}

Metaphors are part of our daily lives helping us understand the world. They become shared habits or frames of thought that shape people's interpretations, inclinations and actions. Economics, as other areas of knowledge or discourse communities, cannot go without metaphors. Remember, for instance, elasticity, social capital, economic growth, technological spill over, production functions and transaction costs as frictions.

Within and around the modern field of economics of organisation, Transaction Cost Economics (TCE) has been established as a major influence. The works of Oliver Williamson in special have given the field a new breadth of life since the 1970s (Pessali 2006). No different to other intellectual constructions, TCE has been built on a set of key metaphors.

Although many studies have addressed a wide range of methodological issues on TCE, the role of its metaphors have yet to be analysed. This article tries to fill such a gap by discussing some of the key metaphors of TCE in terms of their potential to help Williamson's theory gain adherence from and be recognised as relevant by his peers. As such, it intends to contribute to the study of modern economics in its institutions - in this case, part of its rhetoric. It also touches the issue of theoretical lock-ins, or 
how the initial choice or formulation of a metaphor may come to influence the course of the conversations with other approaches and the possibilities of theoretical developments.

The next section intends to warm up the reader already familiar with the study of metaphors and to provide a short introduction to those unfamiliar with the subject. The section finishes by delineating the scope of this paper in terms of the range of metaphors considered. In what follows, three key metaphors of TCE are presented and discussed: transaction costs as frictions, human beings as "contractual men," and natural selection between mechanisms of governance. Some final notes close the essay.

\section{METAPHORS}

According to Aristotle, a "metaphor consists in giving the thing a name that belongs to something else; the transference being either from genus to species, or from species to genus, or from species to species, or on grounds of analogy" (1941:1457b7). They are an attempt to explain something we do not know well in terms of something we think we know better (Black 1993). In a modern survey, Christine Brooke-Rose (1970:23-4) settles on a plain definition of metaphor as "any replacement of one word by another, or any identification of one thing, concept or person with any other."

Since Ramus and Descartes, what we know as positivism has gained momentum in the philosophy of science. It has persuaded many scholars that metaphors are artefacts for entertaining and deceiving discourses and that (good) science, as if by definition, is clear of such devices. Many 
philosophers have since attempted to create a corresponding aseptic language through mathematical systems. They have tried, at the same time, to decree that the study of natural language and argumentation is irrelevant to serious scientific enquiry.

From the mid 1950s, however, there has been increasing recognition that all languages are incomplete systems and have some degree of vagueness and ambiguity. Because science cannot be free of language, it needs to deal with argumentation and less than perfect symbolical exchanges. Knowledge is produced by the articulation of arguments derived from different sources (e.g. induction, deduction and abduction) and established through persuasion of the relevant audience. To articulate our reasoning and produce arguments we employ models, stories, facts and logic (McCloskey 1993:138).

This does not imply that scientific argumentation cannot be rigorous; it just implies that standards of rigour are established by those taking part in the relevant conversation and subject to the imperfections of language (Fernández 2000). Arguments in all their forms, thus, need to be scrutinised in light of such limitations and the demands of those involved in the conversation. ${ }^{1}$

In this context, metaphors used by scientists are not only language ornaments, but constituent parts of how a research object is seen in concrete terms. Metaphors take part in abduction, an essential tool for

\footnotetext{
${ }^{1}$ This concern has been identified as a rhetorical or linguistic turn in western culture, reaching also the scientific arena (e.g. Bazerman 1988 and Fuller 1993).
} 
knowledge acquisition and maintenance, as elements are transferred between different realms of understanding. George Lakoff and Mark Johnson go even further, arguing that our conceptual system is primarily metaphoric (1980:3):

Metaphor is pervasive in everyday life, not just in language but in thought and action. Our ordinary conceptual system, in terms of which we both think and act, is fundamentally metaphorical in nature... the way we think, what we experience, and what we do every day is very much a matter of metaphor.

As tools of reason, metaphors help us pull together our views and perceptions of reality. They take part in shaping our ideas and, thus, in shaping our daily interaction with the world.

Some authors claim that metaphors may help develop an idea in its beginnings, but can be disposed of as the idea matures. ${ }^{2}$ They become "dead metaphors." This, however, may be a misleading metaphor in itself. Just as economists of today do not realise their ideas usually reflect ideas from defunct economists, dead metaphors live on in the ideas it helped articulate. In other words, metaphors leave a structuring legacy to forthcoming generations. This, of course, does not mean that fresher ones will not challenge the established ones at some point.

Philosophy and literary studies were arguably the first fields of modern inquiry to recognise the role of metaphor in the construction of knowledge,

2 According to Arida (2003:40): "The metaphor reaches maximum rhetorical efficiency early in the debate or in presenting original propositions; as the debate progresses, one tries to rely less on it." 
and above all in scientific theorising. ${ }^{3}$ Philosophers and literary critics targeted many scientific fronts, which started to internalise the study of metaphor in their own fields by their fellow researchers. ${ }^{4}$

In economics, some authors (e.g. Henderson 1982; McCloskey 1985) started to acknowledge and study the role of metaphor in the work of their fellow economists, opening the field for further exploration. ${ }^{5}$ Economists converse with their fellows and with other audiences, striving for intellectual endorsement, and conversations are mostly made of language resources by definition. Among them, metaphors have been stressed as essential to the construction and presentation of arguments.

Following the arguments of Klamer \& Leonard (1994), metaphors are studied here in their potential to either facilitate or hamper communication (and persuasion) among certain scientific communities. This essay explores how the main metaphors of TCE can point to a certain rhetorical strategy, or how they help promote identification with or differentiation towards other approaches.

Because of the pervasiveness of metaphors, it is necessary to delineate our scope from the start. First, insofar as theoretical debates in economics are concerned, the main theoretical pillars of TCE are arguably the place where scholars first search for a first hint of relevance. This explains the focus lying mostly, though not exclusively, in the main

\footnotetext{
${ }^{3}$ Black (1962), Hesse (1963) and Perelman \& Olbrechts-Tyteca (1969) are a few wellknown benchmarks.

${ }^{4}$ For a small sample, see Nelson et al. (1987).

${ }^{5}$ See for instance Klamer et al. (1988), Samuels (1990) and Dolfsma (2001).
} 
theoretical chapters of Williamson's trilogy (1975 - Markets and Hierarchies or $\mathrm{MH} ; 1985$ - The Economic Institutions of Capitalism or EIC; and 1996 The Mechanisms of Governance or MG).

Second, the kinds of metaphor considered here are based on the typology suggested by Klamer \& Leonard (1994). They identify three main kinds of metaphors in science: pedagogical, heuristic, and constitutive. Pedagogical metaphors "simply serve to illuminate and clarify an exposition and could be omitted without affecting the argumentation as such," like "time is money" (p. 31). For this reason, they are of little interest here. Heuristic metaphors are "more influential" and "thought-propelling," and "serve to catalyze our thinking, helping to approach a phenomenon in a novel way." They lend themselves to more "systematic and sustained development," as in the case of "human capital" (p. 32). Still more important are constitutive metaphors. These "work on an even more fundamental level. Constitutive metaphors are those necessary conceptual schemes through which we interpret a world that is either unknowable ... or at least unknown," like when one talks about "the genetic code" (p. 39). The last two kinds of metaphor are the ones drawn upon here, as we discuss the metaphors of TCE that are essential to the systematic development of a "distinctive worldview," as Williamson suggested in $\mathrm{MH}$ (p. xii). 


\section{THE CONSTITUTIVE METAPHOR OF TRANSACTION COSTS AS \\ FRICTIONS}

The metaphor of transaction costs as frictions permeates TCE's theoretical

framework. Williamson said in 1971 (p. 113; emphasis added):

A complete treatment of vertical integration requires that the limits as well as the powers of internal organization be assessed. As the frictions associated with administrative coordination become progressively more severe, recourse to market exchange becomes more attractive.

He applies an argument of symmetry to what economists were used to see asymmetrically, the issue of market failures. This is made more evident in Williamson (1973:316; emphasis added): "It is generally acknowledged that a prima facie case for the development of nonmarket ... forms of economic organization can be said to exist whenever the market ... experiences 'frictions. ${ }^{\prime \prime}$

The metaphor of transaction costs as frictions is constitutive as it helps us interpret and look through the world in which TCE is said to be relevant.

In 1975 this property is made clearer ( $\mathrm{MH}: 20$; emphases added):

Although failures can be and often are assessed with respect to a frictionless ideal, my concern throughout the book is with comparative institutional choices. Only to the extent that frictions associated with one mode of organization are prospectively attenuated by shifting the transaction ... to an alternative mode can a failure be said to exist. Remediable frictions thus constitute the conditions of interest.

In EIC, the metaphorical link is also upheld (p. 1; emphasis added): "In mechanical systems we look for frictions ... The economic counterpart of friction is transaction cost." 
Williamson explains later that his engineering studies made the notion of friction (and its relevance) familiar to him. To quote (MG:350):

One of the benefits of my engineering training is that it dealt with real problems and demanded disciplined answers. Perfect gas laws and frictionless systems may be the place to start, but the study of hypothetical ideals quickly gave way to the engineering realities of friction, resistance, turbulence, and the like.

By the time Williamson used the metaphor of friction, economists had already put it to use. Klaes (2000) reminded us that monetary economists were surrounded by mechanical analogies involving friction, usually as difficulties entailed in a barter economy that money could help to ease. ${ }^{6}$ Klaes also identified the moment in which John Hicks accommodated the notion of frictions under the popular category of costs, an insight quickly assimilated in finance and monetary economics. From there, the idea spread out to other fields, including the general equilibrium literature and the analysis of comparative efficiency between market and non-market institutions.

The metaphor of costs as frictions was familiar to economists before its use in TCE. By working with the familiar mechanical metaphor of frictions TCE can make for easier communication with a great number of economists. More generally speaking, the metaphor shapes theoretical exchanges that can direct further developments of TCE. In what follows, some of these possibilities are discussed.

${ }^{6}$ Klaes $(2000: 193)$ recalls the example of Knut Wicksell who compared money to a lubricant that makes the economic machinery run smoothly. 


\section{Transaction costs in a struggle metaphor}

Consider for a moment that the idea of transaction costs could have been advanced with different emphases. In place of stressing the costs of writing and executing contracts between separable technological interfaces, the emphasis is put on the conflict of interests between parties. The notion of transaction costs would then be grounded in a struggle metaphor, where group (or class) disputes would play the central role.

The work of Marglin (1974) is a case in point. In his view, cost effective solutions to the organisation of labour can be obtained through increased control of capitalists over labour (a class struggle argument). This, however, gives room for power explanations, something many economists then and now try to avoid. Williamson addressed this alternative approach (see EIC, chapter 9) as adversarial, not as complementary to TCE. On a later occasion he said (MG: 238): "The concept of power is very diffuse. Unable to define power, some specialists report that they know it when they see it."

The conversation with Marxian economists and a significant part of the sociology of organisations reaches an impasse. Transaction costs as frictions are reduced so economic transactions can be carried out in a smoother way. The landscape of conflicts gives way to a rationale of efficiency. "Frictions" are natural impediments to be dealt with - whether by increased power asymmetry or not does not seem to be the point. 


\section{The engineer, the accountant and the physicist}

As far as economists are concerned, not only transaction costs can be developed as a different metaphor but also the metaphor of transaction costs as frictions can be advanced in different ways. John Wallis and Douglass North (Wallis \& North 1986), for instance, have pursued what Klamer \& McCloskey (1991) would identify as an accounting approach to the economic problem in which measuring the costs is central.

Williamson seems more appreciative of the pragmatic bias of his engineering training (MG:350). Calculations, for instance, are needed to the extent in which viable real alternatives are involved, and formal analysis is to be pursued but not at the cost of a better understanding of the variables at play.

The metaphor of transaction costs as frictions encompasses this disciplined but pragmatic way of reasoning. This probably brings Williamson closer to other scholars of similar frame of mind. Note, for instance, what is said in Williamson (2000:596; emphasis added):

Initial scepticism [about the economics of institutions] has gradually given way to respect - it being the case that economists are very pragmatic people. Tell them something different and consequential about phenomena that are of interest to them and demonstrate that the data are corroborative: that will get their attention.

There are different, though not conflicting, ways to read this statement. It can be read as an appeal: economists should in fact be more like that. It can also be read as a synecdoche: the economists with whom Williamson is familiar have such a frame of mind and he suggests that they are 
representative of the whole of the profession. Alternatively, it can be read as a tautological avowal: economists are pragmatic because their attention has been caught by TCE, a theory that fulfils Williamson's pre-requisites to attracting the attention of pragmatic people.

The pragmatic bias espoused by Williamson and claimed for his fellow economists, however, may not produce a perfect match if compared to what is of interest to them. It is well known that the mainstream of economics has developed increased interest in mathematical abstractions at the expense of "economic realities" (Coase 1988). Precise formulation is highly esteemed, even at the expense of relevance to real problems. The engineer sees systems with friction that can be chosen on a comparative basis. The accountant wants to be meticulous with the numbers and see all frictions accounted for. The physicist, however, has been the economists' idol (Mirowski 1989). In their aspiration to be the physicists of the social sciences, economists have valued the drawing on the blackboard of idealised systems with no friction (Coase 1988). The differences between the engineer's view and both the accountant and the physicist has been an obstacle for TCE to reach the mainstream of economics.

\section{Frictions in related areas}

The metaphor of friction, or more broadly put, the metaphor of economic systems as machines subject to functioning frictions (costs) is not a stranger to organisation and law studies either. In the first case, the notion of transaction costs spread from monetary economics to finance in 
the 1950s (Klaes 2000), and from there to finance management (Dale 1953). The Tobin tax - an idea popularised as "throwing sand in the gears of financial markets" - is a recent related theme of mutual interest.

In the second case, James White (1987) has said that in the traditional view of law as a set of rules, institutions, and processes, "the overriding metaphor is that of the machine; the overriding value is that of efficiency, conceived of as the attainment of certain ends with the smallest possible costs." Williamson felt it proper to present his metaphor to law scholars even before publishing $\mathrm{MH}$ : "Transaction cost analysis ... is appropriate for studying frictions in the system which may prevent the implications of received microtheory from going through" (Williamson 1974:1495). Conciliated with Williamson's pragmatic view, this certainly helps explain why TCE has become a major force in judicial arguments on northAmerican antitrust courts to the point of relegating the powerful arguments of imperfect competition and market failure.

The engineer's pragmatism seems to be Williamson's way of carrying on the constitutive metaphor of transaction costs as frictions. As he sees it, the accountant impulse to measurement may not be as informative as it appears and the risk of premature formalism triggered by economics impulses to emulate physics is to be avoided. Frictions are accounted for in comparative terms and mainly through narrative, not mathematical discourse. On the one hand, Williamson's resilient pragmatism in developing the metaphor facilitates communication with some audiences (e.g. law, organisation studies, non-formalist economists, and other social 
scientists). On the other hand, it creates barriers to reaching the particular audience of mainstream economists.

Williamson is aware that the causes of transaction costs do not fit easily in formal models as the correspondent causes of frictions in physics. He does not seem willing to give up on those factors, though (see Williamson 2000), but this comes at a price. A comment by the game theorist David Kreps (1999: 154) after an attempt to build a formal TCE model illustrates the case: "Since the model is a very bare metaphor, these are not conjectures on which I would care to stake my professional reputation."

\section{THE HEURISTIC METAPHOR OF THE HUMAN BEING AS CONTRACTUAL MAN}

Williamson argues that TCE is an attempt to operationalise Coase's insights. This is an action with a strong pragmatical connotation. The strategy to operationalise TCE, as Klaes (2000:210) notes, has involved not the meticulous elaboration of the notion of transaction costs, but rather the scrutiny of the factors that give rise to them.

In $\mathrm{MH}$, the causes of friction are distinguished between human and environmental. The human factors considered are opportunism and bounded rationality. In Chapter 2 of EIC, Williamson metaphorically describes the human being of TCE as "contractual man." Operating under the metaphor of transaction costs as frictions, thus, there is the heuristic 
metaphor of "contractual man" helping us to approach economic agents in a novel way.

As Klamer \& Leonard (1994:33) say, "Heuristic metaphors usually will not immediately reveal all possible elaborations." For one thing, the very suggestion of leaving the "flash calculator" image of economic man in mainstream economics and rely on another metaphor of a representative agent is a remarkable move. The idea of an alternative representation may work in favour of catching the attention of those critical of the idea of economic man. Considering human beings as the cause of friction reopens the discussion about their relevant economic attributes.

One problem, however, is that "contractual man" not only captures the idea of an opportunistic and rationally bounded individual, but also the idea that these are fundamental traits in a wide range of contractual relations. Many social scientists, economists included, would subscribe to the idea that contracts are relevant, but would resist that contracts are pervasive to the point of describing all relevant economic life. ${ }^{7}$ Therefore, the metaphor of "contractual man" can be isolated. Some may not agree with the contractual world that is implied but still sympathise with the idea of an alternative characterisation of man in economic models. In other words, one could say that the metaphor of "contractual man" can be constitutive if one concurs with the idea of a contractual world. This viewpoint is more easily found in law, sociology, and political science than in economics or organisation studies.

\footnotetext{
${ }^{7}$ See Hodgson (1998) and Simon (1991).
} 
Contractual man may also have helped to create favourable conditions for a change of atmosphere in the economic discussion of human attributes. Klaes \& Sent (2005), for instance, stress the role played by Williamson in the dissemination of the notion of bounded rationality. In addition, researchers in economics and related areas like behavioural economics and managerial approaches to organisation have also taken the notion of opportunism seriously in their work - even if sometimes with critical qualifications.

Although authors of different areas criticise the emphasis TCE gives to opportunism and bounded rationality, few go as far as to suggest that a theory of the firm or of economic organisation would do well in getting rid of those notions altogether. More importantly, stressing opportunism and bounded rationality is one of many other possible elaborations of the metaphor. There are authors who lean on TCE to propose a complementary or "beyond TCE" approach. Even authors that propose a clashing alternative still use TCE as a point of reference for criticism. Some even suggest that "contractual man" is an advance on economic man, even if not as much as one would wish.

Much of the criticism of "contractual man" targets the attention given to opportunism and bounded rationality that comes to the exclusion of other human attributes (Pessali 2006). The metaphor of "contractual man" is moulded by the constitutive metaphor of transaction costs as frictions. As Williamson tries to explain the causes of friction, he stresses human features that are detrimental to the harmony of transactions, leading to the 
necessity of contracts. Organic metaphors, for example, usually emphasise the human traits accountable for cooperation and synergy between specific but integrated functions. To some extent, trust, dignity, loyalty, and other non or less discrediting features of human behaviour can be seen as substitutes for contract and for the calculativeness TCE claims to be involved therein. ${ }^{8}$

Had TCE focused on human features that ameliorate transaction costs, contracts would have lost their importance and contractual man would probably be mischaracterised as such. See for instance the case of atmosphere (MH:38), a subject that was initially considered by Williamson but that has not been developed further. It entails human features that arguably compensate for opportunism. They, however, do not make for the contractual calculativeness claimed in TCE. Williamson, thus, seems compelled to defend contractual man in detriment of a broader approach (see especially Williamson 1993). As a result, a debate that looked promising in terms of increasing the interfaces between TCE and competence-based approaches to the firm has become less productive and more antagonistic. ${ }^{9}$

\footnotetext{
8 This is a backward reading of what Williamson said in MG (p. 245): "I concur with Granovetter that to craft credible commitments ... is to create functional substitutes for trust."

9 See Williamson (1999), Connor \& Prahalad (1996), Ghoshal \& Moran (1996), Hodgson (1998), Langlois \& Foss (1999), Noorderhaven (1995) and Nooteboom (2004).
} 


\section{THE CONSTITUTIVE METAPHOR OF ECONOMIC NATURAL}

\section{SELECTION}

The metaphor of economic selection usually refers to the idea of natural selection in biology. ${ }^{10}$ In TCE, Williamson uses the evolutionary metaphor of selection in conjunction with rather than in substitution for the mechanistic metaphor of transaction costs as frictions.

Chapter 2 of $\mathrm{MH}$ offers the idea that markets and hierarchies deal with uncertainty and complexity in an adaptive way, so as to economise on transaction costs. In EIC, Williamson outlines the larger context in which TCE is to be set (pp. 22-3):

The argument relies in a general, background way on the efficacy of competition to perform a sort between more and less efficient modes and to shift resources in favor of the former. This seems plausible, especially if the relevant outcomes are those which appear over intervals of five and ten years rather than in the very near term. This intuition would nevertheless benefit from a more fully developed theory of the selection process.

More details, including a quote from Herbert Simon, come in a footnote (p. 23, original emphases): "I subscribe to weak-form rather than strong-form selection, the distinction being that 'in a relative sense, the fitter survive, but there is no reason to suppose that they are fittest in any absolute sense'." As for agency, Williamson quotes Frank Knight in support of his conjecture: "men in general, and within limits, wish to behave economically, to make their activities and their organization 'efficient'

${ }^{10}$ Which is known to be a rebound: biology first imported the metaphor from the work of the economist Thomas Malthus on population (Hodgson 1993). 
rather than wasteful" (Knight 1941, quoted in EIC: 241, Williamson's emphasis).

As quoted above, Williamson says in EIC that his use of the metaphor is derived from an intuition that could "benefit from a more fully developed theory of the selection process." Four years later Williamson (1989) touches the issue again in a footnote. As in any complex theory, one expects the author to prioritise time and effort considering that he or she alone cannot elaborate on all aspects of the emerging approach. Consider for instance what Williamson said to Richard Swedberg (1990:122) about the economics of atmosphere, a hot topic in $\mathrm{MH}$ : "Atmosphere does not play a prominent role in The Economic Institutions of Capitalism, but it isn't because I don't think it is important; it is just that I haven't made any headway with it." This may well be the case for TCE's notion of economic selection.

As authors strive to produce compatible arguments, they tend to avoid extensive discussion of possible incompatibilities. Choices regarding theoretical advances, for instance, may intend to avoid elements that suggest incompatibilities. The case of the less than fully developed metaphor of economic natural selection in TCE seems to fit a reading along these lines.

Williamson presents the metaphor without refinements and accepts its insufficient elaboration. Despite that, many authors set themselves to 
debate the idea. ${ }^{11}$ There seem to be at least two ways to go about this fact. One is that TCE became authoritative in the profession and thus no part of it should stand without critical scrutiny, even when half the argument is on a footnote. The other is related to economists recurrently bringing back the selection metaphor from biology, but especially since biology has heightened its status amidst the sciences. Mirowski \& Somefun (1998:332) have noted for instance that "Economists have displayed a distinct tendency to harken back to the earliest versions of selection in order to endow their theories with an evolutionary cast. ${ }^{\prime 12}$ Selection, however, is not a settled matter in economics. In fact, as Hodgson (1993) argues, it is often a contentious issue. Most of the time the metaphor of natural selection seems to be conflated with the operation of an "invisible hand," and appeals to many economists more as a heuristics than as a subject in need of lengthy elaboration.

Detailing one's position means expanding a theoretical set. As a result, there will be more elements inviting all sorts of comparisons and coherence checks, and the chances of a critical reader identifying incompatibilities increase. Metaphors can easily suggest incompatibilities for, although they stress similarities, they bear differences by definition. But nourishing incompatibilities has not been the strategy pursued by Williamson.

According to Perelman \& Olbrechts-Tyteca (1969), there are at least three main approaches to choices involving the avoidance of

\footnotetext{
${ }^{11}$ See Groenewegen \& Vromen (1996) and Winter (1987).

12 Many cases in point are studied in Hodgson (1993).
} 
incompatibilities. The first is the logical approach, "in which the primary concern is to resolve beforehand all the difficulties and problems which can arise ... by applying the rules, laws, and norms one is accepting" (p. 197). The second is the approach of the practical person, "who resolves problems only as they arise, who rethinks his concepts and rules in terms of real situations and of the decisions required for action" (p. 198). The third is the diplomatic approach (p. 198) in which "procedures are invented for preventing an incompatibility from arising or for postponing the moment of decision until a more convenient time."

As one can infer from MG (p. 56-7fn3), the issue of the metaphor of selection that would best suit TCE has not been further developed since EIC. Using a diplomatic approach, Williamson takes in the metaphor in a general sense, avoiding details that could lead to frictions or compromises.

But the selection metaphor has direct implication on testing TCE. According to Williamson (2000: 605), "TCE is an empirical success story ... research has been broadly corroborative of the predictions of transaction cost economics."

Perhaps one obstacle in refining the selection argument is the gap towards operationalising transaction costs in terms of their constituent parts. Given the difficulties in measuring transaction costs directly, empirical tests of TCE are mostly carried out iwith reduced form models. As Masten (1996) noticed, reduced form models are not as comprehensive as one would wish to strongly support the selective predictions of TCE (see David \& Han 2004 and Carter \& Hodgson 2006). The limits of the metaphor 
in terms of testing the argument are twofold. One is that a single transaction feature responds for the selection process whilst TCE defends an interactive set of them. The other is subjecting TCE to ex post rationalisations that are unpopular in economics: by definition, there will be no losers available to be tested in a comparative analysis.

The heuristic use of the selection metaphor in economics has become widely accepted since Armen Alchian`s (1950) formulation of it. Apparently, the effort by some groups of evolutionary economists to further refine the selection metaphor has made only partial inroads on that custom. Considering thus that professional pressure to further develop the subject has been limited and that much of TCE empirical work has been done on the realm of entrepreneurial intentionality rather than on selection results, there seems to be no strong reason for Williamson to change his diplomatic approach.

\section{CONCLUSION}

The main constitutive and heuristic metaphors of TCE - transaction costs as frictions, the human being as contractual man, and economic selection work as ambassadors for TCE. They help establish identification with and differences from other established or developing views on the economics of organisation (and beyond).

The mechanistic metaphor of transaction costs as frictions and the biological metaphor of selection arguably stand out on this regard. They are well known and widely accepted in a general, heuristic form and, as a 
result, they seem to attract a wide audience in economics. They, however, seem to work less successfully with more specific audiences in niches where the metaphors are worked to detail (e.g. evolutionary theories of the firm).

The metaphor of the human being as "contractual man," in its turn, draws on the metonym used initially by neoclassical economists to construct economic man based on rationality and motivation features. Through sharing these two "higher" human sets of structural characteristics with economic man, "contractual man" may still be attractive to mainstream economists as a less restrictive metonym. Indeed, the core of economics seems to have become more receptive to notions like opportunism - although arguably more in connection with agency theory than with TCE. The case for bounded rationality, however, gives less room for enthusiasm. More recently, Williamson (2002) has made more explicit his suggestion that the economics of organisation needs to use the lens of contract in contrast to the lens of choice. The wording is stronger in suggesting not a simple theoretical fine-tuning but a change of weltanschauung.

These tensions have been part of TCE from the beginning. Williamson's framework has made many inroads into economics - even more intensely into the economics of organisation and anti-trust. Its metaphors have shaped the conversations about its merits and problems, indicating where further theoretical developments might, or might not, be expected. Whether it will keep influencing economists' interpretations, inclinations and 
actions will partly depend on how those metaphors can be sustained and articulated in a heterogeneous discourse community.

\section{ACKNOWLEDGMENTS}

I wish to thank Ramon Fernandez, Geoffrey Hodgson, Arjo Klamer and Dorothea Noble for comments on earlier stages of this work.

\section{REFERENCES}

ALCHIAN, Armen (1950) "Uncertainty, evolution, and economic theory," Journal of Political Economy 58:211-221.

Arida, Pérsio (2003) "A história do pensamento econômico como teoria e retórica," in P. Gala and J. Rego, (orgs.) A História do Pensamento Econômico como Teoria e Retórica, São Paulo: Editora 34.

Aristotle (1941) Poetica, in R. McKeon (ed.) The Basic Works of Aristotle, New York: Random House.

Bazerman, Charles (1988) Shaping Written Knowledge, Madison: University of Wisconsin Press.

Black, Max (1962) Models and Metaphors, Ithaca: Cornell University Press.

Black, Max (1993) "More about metaphor," in A. Ortony, (ed.) Metaphor and Thought, Cambridge: Cambridge University Press.

Brooke-Rose, Christine (1970) [1958] A Grammar of Metaphor, London: Secker \& Warburg.

Carter, R. and Hodgson, G. (2006) "The impact of empirical tests of transaction cost economics on the debate on the nature of the firm," Strategic Management Journal 27:461-476.

Clark, Charles (1992) Economic theory and natural philosophy, Aldershot: Edward Elgar.

Coase, Ronald (1988) The Firm, the Market and the Law, Chicago: University of Chicago Press.

Connor, K. and Prahalad, C. (1996) "A resource-based theory of the firm: knowledge versus opportunism," Organization Science 7:477-501.

Dale, Ernest (1953) "New perspectives in managerial decision-making," The Journal of Business of the University of Chicago 26(1):1-8. 
David, R. and Han, S-K. (2004) "A systematic assessment of the empirical support for transaction cost economics," Strategic Management Journal 25 (1):39-58.

Dolfsma, Wilfred (2001) "Metaphors of knowledge in economics," Review of Social Economy 59(1):71-91.

Fernández, Ramón (2000) "McCloskey, Mäki and the Truth," Estudos Econômicos 30(4):597-628.

Fuller, Steve (1993) Philosophy, Rhetoric and the End of Knowledge, Madison: University of Wisconsin Press.

Ghoshal, S. and Moran, P. (1996) "bad for practice: a critique of the transaction cost theory, " Academy of Management Review 21 (1): 1347.

Groenewegen, J. and Vromen, J. (eds.) (1996) Transaction Cost Economics and Beyond, Boston: Kluwer.

Henderson, Willie (1982) "Metaphor in economics," Economics (Winter):147-53.

Hesse, Mary (1963) Models and Analogies in Science, South Bend: University of Notre Dame University.

Hodgson, Geoffrey (1993) Economics and Evolution, Ann Harbor: The University of Michigan Press.

Hodgson, Geoffrey (1998) "Evolutionary and competence-based theories of the firm," Journal of Economic Studies 25(1):25-56.

Klaes, Matthias (2000) "The history of the concept of transaction costs: neglected aspects," Journal of the History of Economic Thought 22(2):191-216.

Klaes, M. and Sent, E. (2005) "A conceptual history of the emergence of bounded rationality," History of Political Economy 37(1):27-60.

Klamer, A. and Leonard, T. (1994) "So what's an economic metaphor?" in P. Mirowski, (ed.) Natural images in economic thought, Cambridge: Cambridge University Press.

Klamer, A. and McCloskey, D. (1991) "Accounting as the master metaphor of economics," European Accounting Review 1:145-60.

Klamer, A., McCloskey, D. and Solow, R., (eds.) (1988) The Consequences of Economic Rhetoric, New York: Cambridge University Press.

Kreps, David (1999). "Markets and hierarchies and (mathematical) economic theory." In CARROL, Glenn R. \& TEECE, David J. (eds) Firms, Markets, and Hierarchies: the transaction cost economics perspective. New York: Oxford University Press, 121-55.

Lakoff, G. and Johnson, M. (1980) Metaphors We Live By, Chicago: The University of Chicago Press. 
Langlois, R. and Foss, N. (1999) "Capabilities and governance: the rebirth of production in the theory of economic organization," Kyklos 52: 20118.

Marglin, Stephen (1974) "What do bosses do? The origins and functions of hierarchy in capitalist production," Review of Radical Political Economics 6:60-112.

Masten, Scott (1996) "Empirical research in transaction cost economics: challenges, progress, directions," in Groenewegen, J., (ed.) Transaction Cost Economics and Beyond. Kluwer: Boston, MA.

McCloskey, Deirdre (1985) The Rhetoric of Economics, Madison: The University of Wisconsin Press.

McCloskey, Deirdre (1993) "The rhetoric of economic expertise," in R. Roberts and J. Good, (eds.) The Recovery of Rhetoric. London: Bristol Classical.

Mirowski, Philip (1989). More Heat Than Light: economics as social physics, physics as nature's economics. Cambridge, UK: Cambridge University Press.

Mirowski, P. and Somefun, K. (1998) "Markets as evolving computational entities," Journal of Evolutionary Economics 8:329-56.

Nelson, J., Megill, A. and McCloskey, D. (eds.) (1987) The Rhetoric of the Human Sciences, Madison: The University of Wisconsin Press.

Noorderhaven, N. (1995) "Trust and transactions: towards transaction cost analysis with a differential behavioral assumption," Tijdschrift voor Economie en Management 15: 5-18.

Nooteboom, Bart (2004) "Governance and competence: how can they be combined?" Cambridge Journal of Economics 28: 505-25.

Perelman, C. \& Olbrechts-Tyteca, L. (1969) [1958], The New Rhetoric: a treatise on argumentation, trans. J. Wilkinson and P. Weaver, Notre Dame: University of Notre Dame Press.

Pessali, Huascar (2006) "The rhetoric of Oliver Williamson's transaction cost economics." Journal of Institutional Economics 2(1): 45-65.

Samuels, Warren (ed.) (1990) Economics as Discourse, Boston: Kluwer.

Simon, Herbert (1991) "Organizations and markets," Journal of Economic Perspectives 5(2):25-44.

Swedberg, Richard (1990) Economics and Sociology: redefining their boundaries, Princeton: Princeton University Press.

Wallis, J. and North, D. (1986) "Measuring the transaction sector in the American economy, 1870-1970," in S. Engerman and R. Gallman, (eds.) Long Term Factors in American Economic Growth. Chicago: University of Chicago Press.

White, James (1987) "Rhetoric and law: the arts of cultural and communal life," in J. Nelson et al. (eds.) The Rhetoric of the Human Sciences, Madison: The University of Wisconsin Press. 
Williamson, Oliver (1971) "The vertical integration of production: market failure considerations," American Economic Review 61(May):112-23.

Williamson, Oliver (1973) "Markets and hierarchies: some elementary considerations," American Economic Review 63(May):316-25.

Williamson, Oliver (1974) "The economics of antitrust: transaction cost considerations," University of Pennsy/vania Law Review 122:1439-96.

Williamson, Oliver (1975) Markets and hierarchies, New York: Free Press.

Williamson, Oliver (1985) The economic institutions of capitalism, New York: Free Press.

Williamson, Oliver (1989) "Transaction Cost Economics," in R. Schmalensee and R. Willig, (eds.) Handbook of Industrial Organization, Amsterdam: North Holland, v. 1.

Williamson, Oliver (1993) "Calculativeness, trust, and economic organization," Journal of Law and Economics 36 (Apr): 453-486.

Williamson, Oliver (1996) The mechanisms of governance, New York: Oxford University Press.

Williamson, Oliver (1999) "Strategy research: governance and competence perspectives," Strategic Management Journal 20: 1087-1108.

Williamson, Oliver (2000) "The New Institutional Economics: taking stock, looking ahead," Journal of Economic Literature 38(Sep):595-613.

Williamson, Oliver (2002) "The theory of the firm as governance structure: from choice to contract," Journal of Economic Perspectives, v. 16(3):171-95.

Winter, Sidney (1987) "Competition and selection," in J. Eatwell, M. Milgate and P. Newman (eds.) The New Palgrave. London: Macmillan Press, v. 1.

Word count: 6440 (including notes and references). 